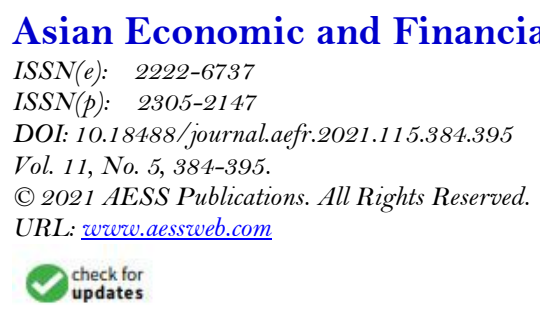

\title{
IS THE STOCK MARKET EFFICIENT? EVIDENCE FROM NONLINEAR UNIT ROOT TESTS FOR NIGERIA
}

\section{Adedoyin Isola \\ LAWAL ${ }^{1+}$ \\ Ezekiel OSENI ${ }^{2}$ \\ Abiola John \\ ASALEYE ${ }^{3}$ \\ Bukola LAWAL- ADEDOYIN ${ }^{4}$ \\ Rachael OJEKA- JOHN $^{5}$}

\author{
${ }^{1,4}$ Dept. of Accounting and Finance, Landmark University, Omu Aran, Nigeria. \\ 'Email:lawal.adedoyin@lmu.edu.ng \\ ${ }^{2}$ Dept. of Banking and Finance, University of Lagos, Nigeria; Bank of Industry, \\ Lagos, Nigeria. \\ ${ }^{s}$ Dept. of Economics, Landmark University, Omu Aran, Nigeria. \\ ${ }^{5}$ Dept. of Mass Communication, Landmark University, Nigeria.
}

Theck for updates

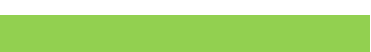

Article History

Received: 21 July 2020

Revised: 13 January 2021

Accepted: 1 April 2021

Published: 23 April 2021

\section{Keywords}

Efficient market hypothesis

Unit root test

Random walk hypothesis

Nonlinearity

ESPAR

Nigeria.

JEL Classification: C12; C22; G12; G14.

\begin{abstract}
This study re-examined the traditional research topic in finance-the efficient market hypothesis (EMH) within the context of a nonlinearity unit root test using daily data sourced on the Nigerian economy. This was premised on two key motivations. First, the study observed that most of the existing studies on EMH are based on an aggregate stock index and the presence of heterogeneity of listed firms on the floor of the exchange can make the results obtained from aggregate stock price-based tests misleading due to spuriousness. To overcome this, the study tested the validity of EMH at a sectorial level. The second motivation centers on the observed nonlinear property of the time series data used in the existing literature. The study first examines the unit root properties of the data by applying the Harvey, Leybourne, and Xiao (2008) methods. The results indicate rejections of the null hypothesis for all the series, an indication that stock market indices in Nigeria are nonlinear and asymmetric in nature. This suggests that results obtained from linear based models could be biased. In order to achieve more accurate results, the study applied the ESPAR model and observed that, overall, there is an abundance of evidence to show that the Nigerian stock exchange is mean reverting, thus investors are advised to adopt a contrarian investment strategy to maximize the opportunities in the market.
\end{abstract}

Contribution/Originality: This study explored the validity of efficient market hypothesis in Nigeria within the context of nonlinear unit root estimates and observed that the market is mean reverting.

\section{INTRODUCTION}

In a nation's economic growth, capital markets play an important role (Asaleye, Popoola, Lawal, Ogundipe, \& Ezenwoke, 2018; Fashina, Asaleye, Ogunjobi, \& Lawal, 2018; Lawal, Nwanji, Adama, \& Otekunrin, 2017). Recently, literature has been dominated by discussions on the performance of the financial market without consensus. Proof of a random or mean reversal mechanism is a crucial function to know whether a market is productive or not. If the market is small, stock prices will be defined as a single root, suggesting permanent shocks with the stochastic 
oscillator component (Akhtar, 2020; Aun, Rizvi, \& Arshad, 2016; Boya, 2019; Durusu-ciftci, Ispir, \& Kok, 2019; Salisu \& Gupta, 2020; Salisu., Vo, \& Lawal, 2020; Vo \& Truong, 2017). Mean reverting, on the other hand, means that market prices shock is transient with stock prices returning to the trend (Lawal, Babajide, Somoye, \& Taiwo, 2019). Inefficient markets are crucial to economic progress and encourage arbitrage opportunities (Arshad, Rizvi, Ghani, \& Duasa, 2016; Isola, Frank, \& Leke, 2015; Lawal, Ozturk, Olanipekun, \& Asaleye, 2020).

The causes of the divergent opinions on the efficiency of the stock market may be based, among other things, on the usage of different approaches with different degrees of restrictive assumptions and/or cycles of different phases of growth. While some studies suggest that stock market behavior does not follow a random walk, Ali, Shahzad, Raza, \& Al-Yahyaee (2018) and Jawad, Shahzad, Hernandez, Al-yahyaee, \& Jammazi (2018) among others, have records indicating that the stock market behaves reliably (Lawal et al., 2019a; Stoian \& Iorgulescu, 2020). This inconclusive debate on the efficiency nature of stock market is not limited to developed markets alone, as evidence abound for Africa economies. For illustration, Benjamin, Duarte, Hernán, \& Sarmiento (2017); He \& Fang (2019) and Otchere \& Abukari (2019), among others, hold a contrary view on the efficiency of African financial markets, whereas (Jarrett, 2010; Narayan \& Popp, 2013) opined that African capital markets are efficient at least in the weak form.

As Hou and Li (2019) observed, stock price nonlinearity is significant in the evaluation of stock market performance as it helps to prevent misleading results. Transaction prices, market friction, noise traders, short sellers, bidding demand distribution and business constraints play a significant role in stock market trading nonlinearity. If the underlying nonlinear dynamics and structural disturbances in the variables studied are neglected, the outcomes derived from linear trials are unreliable and deceptive. Moreover, the linear models are constrained in versatile behavioral description and where the data generation process is nonlinear, linearity-based research has little power to create reliable outcomes, as stated by Aslan and Kum (2011), Lawal, Babajide, Nwanji, and Eluyela (2018a), Yang and Zhao (2020) and Yilanci and Korkut (2020).

Beyond the topic of the nonlinearity of data used to research EMH's validity, most studies rely on an aggregate level evaluation focused on the presumption of business homogeneity. However, homogeneity of corporations does not necessarily indicate that companies vary in scale and cost structure. If the heterogeneity of the business is not considered when taking the sector rather than an aggregate review into consideration, the condition could be incorrectly reported. In addition, a sectoral analysis of the efficiency of bonds gives the economic operators involved insight into where to spend, as it offers a pseudo-sectoral bonds performance analysis.

Extant literature on the Nigerian capital market is centered on the sector's efficiency by using linearity tests based on aggregate bond market data (see, for example, Afego, 2012; Manasseh, Mathew, \& Ogbuabor, 2017; Nwosa \& Oseni, 2011; Obrimah, Alabi, \& Ugo-Harry, 2015). That means that these studies may produce misleading results. The present thesis is a nonlinearity evaluation to review the EMH for the Nigerian stock market with an emphasis on the sectoral examination of the efficiency of the market. This study used a thriving capital market and the largest economy in Africa. For instance, the nation is the second largest recipient (South African, Egyptian) of FDI inflows in Africa (IMF, 2016). Nigeria plays a strategic role in the continent's development. It is the biggest market which has moved seamlessly as a global growth generator (3G) (Lawal, Nwanji, Opeyemi, \& Adama, 2018), and the Nigerian stock exchange activities allow foreign investors to participate easily. Moreover, Nigeria is going through structural reforms and political shifts as a developing economy, which could lead to nonlinear actions for its stock market metrics. It is important to say that the availability of data is the key motivator of Nigeria's selection in this research initiative over and above the established important features of the Nigerian economy. The first study by Harvey et al. (2008) investigated whether linear or nonlinear activity of the Nigerian stock market methodologies has defined the market. We extend the earlier studies by Lawal, Omoju, Babajide, and Asaleye (2019b) and we have continued to assess EMH's validity by using the exponential smooth transition autoregressive procedure smooth and Eastern Settlement (STAR) self-recommended transformation (Stypka \& Wagner, 2019; 
Yaya, Furuoka, Ling, Ikechukwu, \& Ezeoke, 2020). We have also tested the EMH's validity using STAR (Lee, Ranjbar, Jahangard, \& Chang, 2020). Our findings indicate that there is evidence of the nonlinearity and dysfunctionality of the Nigerian stock market.

\section{LITERATURE REVIEW}

Theoretically, empirically and economically, the performance of the capital market has significant consequences. An efficient market means constant stock market shocks, and historic values cannot forecast future returns. Sometimes this scenario illustrates the life of an arbitrary course. On the other hand, an inefficient capital market means that there is evidence that there is a steady pattern in the actions of stocks and that shocks on asset prices are fleeting. Thus, price variations return over time to the trend and predictions can be made on the basis of historical prices under these circumstances. Inefficient markets are important for growth, but recent evidence that capital markets can be harmful to economic growth has been seen in the global financial crises.

The results on stock market efficiency are, at best, mixed. For example, Rejichi and Aloui (2012) and Al-Faryan and Dockery (2020) are of the view that random walk hypothesis holds; others, such as Yilanci and Korkut (2020), Yaya et al. (2020) and Vo and Truong (2017), hold a contrary view that negates the existence of random walks for stock markets. The variations in literature may be attributed to numerous approaches, including periods of economic life. To boost stock returns in an inefficient market, investors follow an opposite investment strategy, as winner-loser reversals can occur. On the other hand, intelligent investors will follow an aggressive market-based competitive investment approach.

Existing literature on the Nigerian capital market is mixed. For example, while Ayadi (1984), Omole (1997) and Olowe (1999) documented the validity of the efficient market hypothesis for Nigeria, others, for instance, Oludoyi (1997), Adelegan (2004); Nwosa and Oseni (2011); Afego (2012); Ayopo, Isola, and Somoye (2015); Ayopo, Isola, and Olukayode (2016a); Ayopo, Isola, and Olukayode (2016b) and Lawal, Somoye, and Babajide (2017), established market inefficiency for Nigeria.

The unit root property of the data generation process is critical, as Kim and Ryu (2015) pointed out, in order to clarify the true essence of the capital market efficiency. If the unit root property of the data is not examined before we conduct empirical verification of the stock market, the findings may be deceptive. In the same way, the main facets of sectoral research of stock market performance have also been underlined by Narayan, Lui, and Westerlund (2016). They pointed out that it is not only the presumption of homogeneity by businesses that is the big driving force behind aggregate stock pricing.

Extant literature on the Nigeria stock market failed to consider the nonlinear property of the data employed. This thesis aims to fill this void by calibrating the nonlinear property of the data generating set to the unit root test. The study also factored sectorial analysis into its model.

\section{DATA AND METHODOLOGY}

Data for this study was sourced from January 03, 1986 to December 30, 2019. The study used daily data on Nigeria's All Share Index (ASI) for eleven sub-sectors that constitute trading on the floor of the Nigeria stock market; these sectors are financial services, agriculture, conglomerations, telecommunications, consumer goods, oil and gas, aviation, dairy and food products, automobile and transport, pharmaceutics and health care, and hospitality. Data for the study was obtained from the publications on CashCraft (www.cashcraft.com).

\section{Methods}

In order to ascertain the unit root properties of the data, Harvey et al. (2008) proposed two types of models: (i) when the time series are stationary $(1(0))$; and (ii) when the series are non-stationary $(1(1))$. In the first scenario, the model is as follows: 


$$
\kappa_{t}=\beta_{0}+\beta_{1} \kappa_{t-1}+\beta_{2} \kappa_{t-2}^{2}+\beta_{3} \kappa_{t-3}^{3}+\sum_{j=1}^{p} \beta_{4, j} \Delta \kappa_{t-j}+\varepsilon_{t}
$$

where $\mathrm{p}$ is the number of lags and $\Delta$ is the first difference operator. We tested for the null hypothesis of linearity $\left(\mathrm{H}_{0}, 1(0): \beta_{2}=\beta_{3}=0\right)$ against the alternatives hypothesis of nonlinearity $\left(\mathrm{H}_{1}, 1(0): \beta_{2} \neq 0\right.$ and/or $\left.\beta_{3} \neq 0\right)$ using the Wald statistics, defined as $w_{0}=T\left(R S S_{0}^{r} / R S S_{0}^{u}-1\right)$. T is the number of observations, $R S S_{0}^{r}$ and $R S S_{0}^{u}$ are the residual sums of square from the unrestricted and restricted forms of Equation 1, respectively.

When the series are non-stationary (1(1)), the regression equation for the second scenario is as presented in Equation 2 below:

$$
\Delta \kappa_{t}=\lambda_{1} \Delta \kappa_{t-1}+\lambda_{2}\left(\Delta \kappa_{t-1}\right)^{2}+\lambda_{3}\left(\Delta \kappa_{t-1}\right)^{3}+\sum_{j=1}^{p} \lambda_{4, j} \Delta \kappa_{t-j}+\varepsilon_{t}
$$

The null hypothesis of linearity $\left(\mathrm{H}_{0,1(1)}: \lambda_{2}=\lambda_{3}=0\right)$ was tested against the alternative hypothesis of nonlinearity $\left(\mathrm{H} 1,1(0): \lambda_{2} \neq 0\right.$ and/or $\left.\lambda_{3} \neq 0\right)$ by the Wald statistics, defined as $W_{1}=T\left(R S S_{1}^{r} / R S S_{1}^{u}-1\right)$, where $R S S_{1}^{r}$ and $R S S_{1}^{u}$ are as earlier defined.

\subsection{Nonlinear Unit Root Rest Estimates}

It has been established in literature that when the true data generating process (DGP) is nonlinear, linearitybased test techniques have low power, thus generating biased results. To overcome this, it is ethical to employ a nonlinear unit root test. Following Aslan \& Kum, (2011); Galadima \& Aminu, (2019); Yang \& Zhao, (2020); Yilanci \& Korkut, (2020), the study employed the below exponential smooth transition autoregressive process (ESTAR), such that:

$$
Z_{t}=Z_{t-1}+\xi Z_{t-1}\left\{1-\exp \left(-\theta Z_{t-d}^{2}\right)\right\}+\epsilon_{t}
$$

Here, $\theta$ is a strictly positive scale parameter, such that $0<\exp \left(-\theta Z_{t-d}^{2}\right)<1$ represents a delay parameter. It is interesting to note that when $r_{t-d}$ is very big (when sectorial stock price indices significantly deviate from the national index), $\exp \left(-\theta Z_{t-d}^{2}\right)$ becomes smaller, converging towards 0 . The implication for this is that the stochastic process (3) becomes a stationary $\operatorname{AR}(1)$ process $(1+\xi=p<1)$. However, when $Z_{t-d}$ is close to zero, the $Z_{t}$ becomes a unit root process. Equation 3 can be re-written as presented in Equation 4 below:

$$
\Delta Z_{t}=\xi Z_{t-1}\left\{1-\exp \left(-\theta Z_{t-d}^{2}\right\}+\epsilon_{t}\right.
$$


Here, $\xi$ is not identified under the unit root null hypothesis; this is referred to as "the Davies problem". To address this problem, Kapetanios, Shin, and Snell (2003) employed a transformative measure of the Taylor series expansion, as stated below in Equation 5:

$$
\Delta Z_{t}=\delta Z_{t-1}^{3}+\epsilon_{t}
$$

The least square t-statistics for $\delta$ under the unit root null has the following asymptotic distribution:

$$
\frac{\frac{1}{4} W(1)^{2}-\frac{s}{2} \int_{0}^{1} W(1)^{2} d s}{\sqrt{\int_{0}^{1} W(1)^{6} d s}}
$$

where $\mathrm{W}(\boldsymbol{z})$ represents the standard Brownian motion defined by $\mathrm{s} \boldsymbol{\epsilon}[0,1]$. When the error terms $\left(\boldsymbol{\varepsilon}_{t}\right)$ are serially correlated, Equation 6 can be augmented, such that:

$$
\Delta Z_{t}=\delta Z_{t-1}^{3}+\sum_{j=1}^{k} \beta_{j} \Delta Z_{t-j}+\epsilon_{t}
$$

We examined the data for situations where an intercept is included and when the intercept and time trends are involved, as presented in Equation 7.

To further establish the reliability of the results, the study examined the existence, or otherwise, of structural breaks in the model by employing the recently developed GARCH unit root test by Narayan and Liu (2015). The Narayan and Liu (2015) unit root test allows for up to two structural breaks, has better size and power, and addresses the presence of heteroskedasticity and structural breaks simultaneously, which gives more robust results when compared with other unit root tests, such as the augmented Dickey-Fuller (ADF) (Lee and Strazicich, 2003; Narayan and Popp, 2010; Lawal, Nwanji, Asaleye, \& Ahmed, 2016). Following Mishra, Mishra, \& Smyth (2014), we considered a GARCH $(1,1)$ unit root test, as stated in Equation 8:

$$
y_{t}=\alpha_{0}+\pi y_{t-1}+D_{1} B_{1 t}+D_{2} B_{2 t}+\varepsilon_{t}
$$

Where $B_{1 t}=1$ for $\mathrm{f}>\mathrm{TB}_{1}=0, \mathrm{~TB}_{1}$ represents the structural break points, such that $\mathrm{i}=1,2 . \mathrm{D}_{1}$ and $\mathrm{D}_{2}$ represent break dummy coefficients. The Narayan and Liu (2015) study was a test of joint maximum likelihood (ML) and used a sequential procedure to derive the estimate break dates. It also used the ML t-ratio to test $\pi$ with a heteroskedasticity consistent covariance matrix.

\section{RESULTS AND DISCUSSION}

Table 1 below presents the descriptive statistics of the data employed in the current study. The stocks are subdivided into 11 industries based on the Nigerian stock exchange business listing classification. These industries include financial services, agriculture, clusters, ICT, manufactured products, oil and gas, services, consumer goods, building and property, healthcare, and natural resources. Financial services have the greatest number of businesses with 62 firms, it was followed by consumer sub-sectors with thirty-four (34) firms and the services sector with twenty-four (24) firms. The lowest, with just four (4) companies listed on the stock market, is natural resources. Results revealed that the average returns on stocks differ from sector to business, varying from 0.52 to 1.960 . The average return on agricultural products is $0.52 \%$; the average returns on manufactured goods is $0.788 \%$. The findings of the volatility displayed by the coefficient of variation $(\mathrm{CoV})$ show that the volatility ranges across 
sectors with ICT accounting for 13.592, which is the largest, followed by industrial goods at 13.012. With a CoV of around 4.911, the consumer products market tends to be the least unpredictable. The kurtosis suggests that all sectors on the stock exchange are leptokurtic, which indicates a wide distribution of the variables. The findings of the skewness test are associated with kurtosis in both fields.

Table 1. Descriptive Statistics.

\begin{tabular}{l|c|c|c|c|c|c|c|c}
\hline Sectors & $\begin{array}{c}\text { No. of } \\
\text { stocks }\end{array}$ & Mean & $\begin{array}{c}\text { Standard } \\
\text { Deviation }\end{array}$ & $\mathbf{C o V}$ & Skewness & Kurtosis & AC $_{1}$ & AC $_{12}$ \\
\hline Financial services & 62 & 0.987 & 2.940 & 5.828 & -0.348 & 10.233 & 13 & 2 \\
\hline Agriculture & 10 & 0.52 & 1.54 & 8.416 & -0.323 & 4.28 & 6 & 3 \\
\hline Conglomerates & 12 & 0.81 & 2.321 & 7.084 & -0.613 & 5.176 & 4 & 3 \\
\hline ICT & 14 & 0.61 & 2.142 & 13.592 & -0.474 & 4.093 & 7 & 3 \\
\hline Industrial goods & 17 & 0.834 & 1.7891 & 13.012 & -0.024 & 4.787 & 8 & 5 \\
\hline Oil \& gas & 13 & 0.514 & 2.109 & 12.201 & -0.522 & 4.923 & 7 & 3 \\
\hline Services & 24 & 0.461 & 2.4412 & 8.449 & -0.322 & 4.8521 & 8 & 3 \\
\hline Consumer goods & 34 & 1.960 & 4.180 & 4.911 & -0.582 & 4.713 & 9 & 3 \\
\hline Construction \& real estate & 7 & 0.801 & 4.137 & 6.134 & -1.721 & 7.992 & 10 & 2 \\
\hline Healthcare & 11 & 0.548 & 4.0098 & 5.042 & -0.924 & 7.609 & 11 & 6 \\
\hline Natural resources & 4 & 0.946 & 5.1331 & 5.332 & -0.6108 & 7.9111 & 8 & 3 \\
\hline
\end{tabular}

The study employed the method used by Harvey et al. (2008) to examine whether the sequence is distinguished or not by a linear or nonlinear pattern. The null hypothesis of linearity for all series is rejected at least 5 percent in value from the findings presented in panel A of Table 2. This indicates that there is clear evidence of a nonlinear trend in Nigerian stock market indexes and an asymmetrical existence in stock market indices in Nigeria. This means that it may be misleading to rely on the results from a linear model and validates the use of a nonlinear model, which is at the core of the current study.

Table 2. Linearity Unit Root Test and Univariate Nonlinear Unit Root Test.

\begin{tabular}{|c|c|c|}
\hline \multicolumn{3}{|c|}{ Panel A: Linearity Unit Root Test } \\
\hline Index & & $\mathbf{w} \lambda$ statistics \\
\hline \multicolumn{2}{|l|}{ Financial services } & $13.05^{* * * *}$ \\
\hline \multicolumn{2}{|l|}{ Agriculture } & 12.41 *** \\
\hline \multicolumn{2}{|l|}{ Conglomerates } & $28.02^{* * * *}$ \\
\hline \multicolumn{2}{|l|}{ ICT } & $24.11^{* * * * *}$ \\
\hline \multicolumn{2}{|l|}{ Industrial goods } & $22.22 * * *$ \\
\hline \multicolumn{2}{|l|}{ Oil and gas } & $27.26^{* * * *}$ \\
\hline \multicolumn{2}{|l|}{ Services } & $54.52^{*} * *$ \\
\hline \multicolumn{2}{|l|}{ Consumer goods } & 23.51 *⿻丷木 \\
\hline \multicolumn{2}{|l|}{ Constructions and real estate } & $25.45^{*} * \frac{1}{2}$ \\
\hline \multicolumn{2}{|l|}{ Healthcare } & $22.42^{* * * *}$ \\
\hline \multicolumn{2}{|c|}{ Natural resources } & $33.42^{* * * *}$ \\
\hline \multicolumn{3}{|c|}{ Panel B: Univariate Nonlinear Unit Root Tests } \\
\hline Sectorial index & $\mathrm{NLADF}_{\mathrm{t}}$ & $\mathrm{NLADF}_{\mathrm{C}}$ \\
\hline Financial services & -2.342 & -3.118 \\
\hline Agriculture & $-2.020^{*} * * *$ & $-3.292^{*} * * *$ \\
\hline Conglomerates & -2.119 & $-2.017 * *$ \\
\hline ICT & $-3.296 * *$ & -3.661 **** \\
\hline Industrial goods & -3.762 & $-2.811^{* *}$ \\
\hline Oil \& gas & -2.421 & -2.840 \\
\hline Services & $-1.816^{* * *}$ & -2.911 **** \\
\hline Consumer goods & $-3.274 * *$ & $-2.445 * *$ \\
\hline Construction \& real estate & $-2.632^{*}$ & $-2.522^{* *}$ \\
\hline Healthcare & $-2.511^{*} * * *$ & $-2.402^{* * *}$ \\
\hline Natural resources & $-2.280^{*}$ & $-3.033^{* *}$ \\
\hline
\end{tabular}


Panel B of Table 2 displays the effects of the nonlinearity root test for the sequence. The findings show that out of the eleven sectors that make up the Nigerian capital market, we are rejecting the null hypothesis for no fewer than eight sectors. This suggests that there is evidence of a medium shift of 72 percent of stocks on the trading floor, while there is evidence of a spontaneous walking activity for the remaining 27 percent. The examination, if we permit a time pattern, rejects the null for a further two industries-industrial and conglomerates. The effect of the mean reversal mechanism increased to about 84 percent. This is consistent with Charfeddine and Khediri (2016) who found that GCC market efficiency and inefficiency elements found among such markets differ from time to time. Arshad et al. (2016) published similar findings for the (Organization of Islamic Cooperation) OIC -markets. Our findings, however, contradict Afego (2012) and Nwosu, Orji, \& Anagwu (2013) who pointed out the vulnerability of the efficacy, at least, of the African stock market.

Table 3. Narayan and Liu $(2015)$ GARCH $(1,1)$ Unit Root Test with two structural breaks in the intercepts.

\begin{tabular}{|c|c|c|c|}
\hline Sector & Test Statistic & TB1 & TB2 \\
\hline Financial services & -3.832 & $22^{\text {nd }}$ June, 2009 & $19^{\text {th }}$ Aug., 2012 \\
\hline Agriculture & $-3.4411^{* *}$ & $18^{\text {th }}$ July, 2014 & $13^{\text {th }}$ Nov., 2018 \\
\hline Conglomerates & $-2.44^{* *}$ & $15^{\text {th }}$ April, 2001 & $20^{\text {th }}$ Oct., 2002 \\
\hline ICT & $-3.21 * *$ & $17^{\text {th }}$ July, 2004 & $24^{\text {th }}$ Aug., 2014 \\
\hline Industrial goods & -1.155 & $18^{\text {th }}$ Oct., 2004 & $20^{\text {th }}$ Dec., 2013 \\
\hline Oil and gas & -2.137 & $15^{\text {th }}$ April, 2007 & $14^{\text {th }}$ Jan., 2017 \\
\hline Services & $-4.2201 * *$ & $5^{\text {th }}$ Sept., 2006 & $28^{\text {th }}$ May, 2014 \\
\hline Consumers goods & $-2.181^{* *}$ & $4^{\text {th }}$ Nov., 2001 & $18^{\text {th }}$ Nov., 2012 \\
\hline Construction and real estate & $-3.118^{* *}$ & $21^{\text {st }}$ June, 2008 & $12^{\text {th }}$ Dec., 2018 \\
\hline Healthcare & $-1.227^{* * * *}$ & $17^{\text {th }}$ Feb., 2009 & $7^{\text {th }}$ Oct., 2016 \\
\hline Natural resources & $-2.114^{* *}$ & $28^{\text {th }}$ March, 2007 & $24^{\text {th }}$ May, 2018 \\
\hline
\end{tabular}

In Table 3, the GARCH (1) unit root test results with intercept breakdowns for Narayan and Liu (2015) are presented. The findings revealed that in eight of the eleven industries comprising the Nigerian Stock Exchange there was a major turnaround. These findings further reinforce the need to influence the heteroskedasticity of businesses when considering stock market performance.

The cycles analyzed have been marked by a variety of drastic shifts that may affect Nigeria's economic, social and political life. Incidents which may have contributed to systemic breaks observed in the Nigerian stock market are discussed below.

The interruption dates can be attributed to the instability of budgets resulting in poor government spending, with many unfinished construction programs marked by large accumulations in civil sector payroll and government employer compensation. As market liquidity has been dramatically affected, uncertainty in the market has risen.

The level of insurgency increased, especially in the northeastern region of the country, between June 2013 and December 2016. The effects on farm production and the stock market are important, the threat of Boko Haram grew and the local farmers' crisis spread throughout the world like wildfire.

With a high dependency on oil, the Nigerian economy is monocultured. Instability in the oil sector also passes into the real sector as Nigerian government spending is closely accompanied by the present revenues, resulting in a direct transmission to the domestic real economy of fluctuation in oil income. Experience indicates that the fiscal expansion triggered by higher oil income is also marked by a rise in domestic currencies, causing Dutch disease syndrome, decreasing non-oil competition and stock market uncertainty.

Adopting fiscal restraint action with deliberate attempts to disconnect oil revenue and existing fiscal spending, at the end of 2003 the foreign reserve rose to roughly US\$38 trillion in July 2006 from US $\$ 7.5$ trillion. In terms of the rise in private sector credit rates by 30.8 percent in 2005 , well above the target of 22.5 percent, Nigeria's fiscal and monetary policies are dramatically improving in the public and private sectors. 
A number of changes were enacted between 1999 and 2006 that sharpened Nigeria's economic life. Privatization (including privatization of financial services) and financial system and trade policy reforms are some of the most important improvements. In this time, a total of 116 corporations were privatized (Ikechukwu, 2013). The restructuring of the banking sector characterized the consolidation of the banking sector, which lasted from the middle of 2004 to December 2005. A total of US $\$ 3$ billion from the domestic economy and about US $\$ 625$ million from the international community was mobilized from the Nigerian stock exchange.

A number of international events have improved Nigeria's financial structure in addition to these important domestic events. These include, but are not limited to, the global financial crisis/economic recession of 2007-2008, the terrorist attack on the United States on September 11, 2011, the war between the United States and Afghanistan, the war between the United States and Iraq, and the Arab Spring.

\section{POLICY IMPLICATION}

The dismissal by 88 percent of the industries of the null hypothesis has political consequences. First, these results show that the Nigerian stock market is inefficient and has a substantial reversal mechanism, which indicates that market disruptions are transient. This offers space for arbitration on the market. It also means that investors will follow opposite investing strategies with short better-performing assets when purchasing worse returns, as there is a chance of winner-loser reversals where there are significant divergences within the markets. Second, as there is much evidence that both stationary and non-stationary series comprise Nigeria's stock index, and that a high percentage is stationary, investors should participate aggressively in stationary stock transactions in order to optimize their earnings (Narayan, Narayan, \& Westerlund, 2015; Phan, Sharma, \& Narayan, 2015a, 2015b; Westerlund, Narayan, \& Zheng, 2015). Third, the outcome of this study demonstrates that foreign investors can create a successful investment policy by using the price data to benefit from arbitration opportunities within the market in view of the inefficiencies of the Nigerian stock market. The study also indicates that there are great opportunities for the Nigerian market to add to economic development by drawing capital into the economy locally as well as globally.

\section{CONCLUSION}

In the form of the nonlinearity unit root test, the validity of the efficient market hypothesis (EMH) of the industry in Nigeria was re-examined based on regular data obtained between January 3, 1986 and December 30, 2019. The research focused on sectoral analysis, as opposed to current literature concerning the Nigerian economy, which uses aggregate data. This is premised on the probability of variability among companies listed on the exchange floor, which results in errors arising from aggregate data because of falsity.

The nonlinearity of the data generation process is also an encouragement. The research analyzed the root unit properties of the data using models from Harvey et al. (2008), which revealed the nonlinear and asymmetric stock market indexes in Nigeria. This motivates the ESPAR model to investigate whether a random phase or reversal is being carried out by the Nigerian stock exchange. The outcome shows that, in general, the bourse of Nigeria means a return, so investors can optimize the market by a policy of contrary investment.

Funding: This research is funded by University, Omu Aran, Nigeria.

Competing Interests: The authors declare that they have no competing interests.

Acknowledgement: All authors contributed equally to the conception and design of the study.

\section{REFERENCES}

Adelegan, O. J. (2004). How efficient is the Nigerian stock market? Further evidence. African Review of Money Finance and Banking, 8(2), 145-165. 
Afego, P. (2012). Weak form efficiency of the Nigerian stock market: An empirical analysis (1984 - 2009). International Journal of Economics and Financial Issues, 2(3), 340-347.

Akhtar, T. (2020). Market multiples and stock returns among emerging and developed financial markets. Borsa Istanbul Review.Available at: https://doi.org/10.1016/j.bir.2020.07.001.

Al-Faryan, M. A. S., \& Dockery, E. (2020). Testing for efficiency in the Saudi stock market: does corporate governance change matter? Review of Quantitative Finance and Accounting, 1-30.Available at: https://doi.org/10.1007/s1 1156-020-00939-0.

Ali, S., Shahzad, S. J. H., Raza, N., \& Al-Yahyaee, K. H. (2018). Stock market efficiency: A comparative analysis of Islamic and conventional stock markets. Physica A: Statistical Mechanics and Its Applications, 503, 139-153.Available at: https://doi.org/10.1016/j.physa.2018.02.169.

Arshad, S., Rizvi, S. A. R., Ghani, G. M., \& Duasa, J. (2016). Investigating stock market efficiency: A look at OIC member countries. Research in International Business and Finance, 36, 402-413.Available at: https://doi.org/10.1016/j.ribaf.2015.09.026.

Asaleye, A. J., Popoola, O., Lawal, A. I., Ogundipe, A., \& Ezenwoke, O. (2018). The credit channels of monetary policy transmission: Implications on output and employment in Nigeria. Banks and Bank Systems, 13(4), 103-1 18.Available at: http://dx.doi.org/10.21511/bbs.13(4).2018.10.

Aslan, A., \& Kum, H. (2011). The stationary of energy consumption for Turkish disaggregate data by employing linear and nonlinear unit root tests. Energy, 36(7), 4256-4258.Available at: https://doi.org/10.1016/j.energy.2011.04.018.

Aun, S., Rizvi, R., \& Arshad, S. (2016). Borsa _ Istanbul review How does crisis affect efficiency ? An empirical study of East Asian markets. Borsa Istanbul Review, 16(1), 1-8.Available at: https://doi.org/10.1016/j.bir.2015.12.003.

Ayadi, F. (1984). The random walk hypothesis and the behaviour of share prices in Nigeria. Nigerian Journal of Economic and Social Studies, 26(1), 57-71.

Ayopo, B. A., Isola, A. L., \& Somoye, R. O. C. (2015). Monetary policy dynamics and the stock market movements: Empirical evidence from Nigeria. Journal of Applied Economic Sciences, X38(8), 1179-1188.

Ayopo, B. A., Isola, L. A., \& Olukayode, S. R. (2016a). Stock market response to economic growth and interest rate volatility: Evidence from Nigeria. International Journal of Economics and Financial Issues, 6(1), 354-360.

Ayopo, B. A., Isola, L. A., \& Olukayode, S. R. (2016b). Stock market volatility: Does our fundamentals matter? Economic Research, 25(3), 33-42.

Benjamin, J., Duarte, D., Hernán, L., \& Sarmiento, T. (2017). Evaluation of the effect of investor psychology on an artificial stock market through its degree of efficiency. Accounting and Administration, 62(4), 1361-1376.Available at: https://doi.org/10.1016/j.cya.2017.06.014.

Boya, C. M. (2019). From efficient markets to adaptive markets: Evidence from the French stock exchange. Research in International Business and Finance, 49, 156-165.Available at: https://doi.org/10.1016/j.ribaf.2019.03.005.

Charfeddine, L., \& Khediri, K. B. (2016). Time varying market efficiency of the GCC stock markets. Physica A: Statistical Mechanics and Its Applications, 444, 487-504.Available at: https://doi.org/10.1016/j.physa.2015.09.063.

Durusu-ciftci, D., Ispir, M. S., \& Kok, D. (2019). Do stock markets follow a random walk? New evidence for an old question. International Review of Economics and Finance, 64(April), 165-175.Available at: https://doi.org/10.1016/j.iref.2019.06.002.

Fashina, O. A., Asaleye, A. J., Ogunjobi, J. O., \& Lawal, A. I. (2018). Foreign aid, human capital and economic growth nexus: Evidence from Nigeria. Journal of International Studies, 11(2), 104-117.Available at: https://doi.org/10.14254/20718330.2018/11-2/8.

Galadima, M. D., \& Aminu, A. W. (2019). Nonlinear unit root and nonlinear causality in natural gas - economic growth nexus: Evidence from Nigeria. Energy, 1 16415.Available at: https://doi.org/10.1016/j.energy.2019.116415.

Harvey, D. I., Leybourne, S. J., \& Xiao, B. (2008). A powerful test for linearity when the order of integration is unknown. Studies in Nonlinear Dynamics \&̊ Econometrics, 12(3), 1-24.Available at: https://doi.org/10.2202/1558-3708.1582. 
He, Q., \& Fang, C. (2019). Regulatory sanctions and stock pricing efficiency: Evidence from the Chinese stock market. PacificBasin Finance Journal, 58, 101241.Available at: https://doi.org/10.1016/j.pacfin.2019.101241.

Hou, Y., \& Li, S. (2019). Volatility and skewness spillover between stock index and stock index futures markets during a crash period: New evidence from China. International Review of Economics \& Finance, 66, 166-188.Available at: https://doi.org/10.1016/j.iref.2019.11.003.

Ikechukwu, O. I. (2013). Privatization of public enterprises in Nigeria. Developing Country Studies, 3(3), 1-6.

IMF. (2016). International monetary fund world outlook. Retrieved from: https://www.imf.org/en/Publications/WEO/Issues/2016/12/31/Subdued-Demand-Symptoms-and-Remedies.

Isola, L. A., Frank, A., \& Leke, B. K. (2015). Can Nigeria achieve Millennium development goals? The Journal of Social Sciences Research, 1(6), 72-78.

Jarrett, J. E. (2010). Efficient markets hypothesis and daily variation in small Pacific-basin stock markets. Management Research Review, 33(12), 1128-1 139.Available at: https://doi.org/10.1108/01409171011092185.

Jawad, S., Shahzad, H., Hernandez, J. A., Al-yahyaee, K. H., \& Jammazi, R. (2018). Asymmetric risk spillovers between oil and agricultural commodities. Energy Policy, 118, 182-198.Available at: https://doi.org/10.1016/j.enpol.2018.03.074.

Kapetanios, G., Shin, Y., \& Snell, A. (2003). Testing for a unit root in the nonlinear STAR framework. Journal of Econometrics, 112(2), 359-379.Available at: https://doi.org/10.1016/s0304-4076(02)00202-6.

Kim, H., \& Ryu, D. (2015). Measuring the speed of convergence of stock prices: A nonparametric and nonlinear approach. Economic Modelling, 51, 227-241.Available at: https://doi.org/10.1016/j.econmod.2015.07.009.

Lawal, A. I., Babajide, A. A., Nwanji, T. I., \& Eluyela, D. (2018a). Are oil prices mean reverting ? Evidence from unit root tests with sharp and smooth breaks. International Journal of Energy Economics and Policy, 8(6), 292-298.

Lawal, A. I., Nwanji, T. I., Adama, J. I., \& Otekunrin, A. O. (2017). Examining the Nigerian stock market efficiency: Empirical evidence from wavelet unit root test approach. Journal of Applied Economic Science, 12(6), 1680-1689.

Lawal, A. I., Nwanji, T. I., Asaleye, A., \& Ahmed, V. (2016). Economic growth, financial development and trade openness in Nigeria: An application of the ARDL bound testing approach. Cogent Economics and Finance, 4, 1258810.Available at: http://dx.doi.org/10.1080/23322039.2016.1258810.

Lawal, A. I., Olayanju, A., Salisu, A. A., Asaleye, A. J., Dahunsi, O., Dada, O., \& Popoola, O. R. (2019a). Examining rational bubbles in oil prices: Evidence from frequency domain estimates. International Journal of Energy Economics and Policy, 9(2), 166-173 Available at: https://doi.org/10.32479/ijeep.7463.

Lawal, A. I., Omoju, O. E., Babajide, A. A., \& Asaleye, A. J. (2019b). Testing mean-reversion in agricultural commodity prices: Evidence from wavelet analysis. Journal of International Studies, 12(4), 100-1 14.

Lawal, A. I., Babajide, A. A., Somoye, R. O. C., \& Taiwo, J. N. (2019). Re-examining stock market efficiency in Nigeria using nonlinear unit root tests. The impacts of monetary policy in the 21st century: Perspectives from emerging economies. UK: Emerald Publishers.

Lawal, A. I., Ozturk, I., Olanipekun, I. O., \& Asaleye, A. J. (2020). Examining the linkages between electricity consumption and economic growth in African economies. Energy, 208, 118363.Available at: https://doi.org/10.1016/j.energy.2020.118363.

Lawal, A. I., Nwanji, T. I., Opeyemi, O. O., \& Adama, I. J. (2018). Can corporate governance mechanisms deter earnings management? Evidence from firms listed on the Nigerian stock exchange. Aestimatio: The IEB International Journal of Finance, 17, 220-233.Available at: https://www.ieb.es/aestimatio-no-17-2018/.

Lawal, A. I., Somoye, R. O., \& Babajide, A. A. (2017). Are African stock markets efficient? Evidence from wavelet unit root test for random walk. Economics Bulletin, 37(4), 2665-2679.

Lee, J., \& Strazicich, M. C. (2003). Minimum Lagrange multiplier unit root test with two structural breaks. Revierw of Economics and Statistics, 85(4), 1082-1089.Available at: https://doi.org/10.1162/003465303772815961. 
Lee, Y.-L., Ranjbar, O., Jahangard, F., \& Chang, T. (2020). Analyzing slowdown and meltdowns in the African countries: New evidence using Fourier quantile unit root test. International Review of Economics \& Finance, 65, 187-198.Available at: https://doi.org/10.1016/j.iref.2019.10.008.

Manasseh, C. O., Mathew, T. E., \& Ogbuabor, J. E. (2017). Investigating the nexus between institutional quality and stock market development in Nigeria: An autoregressive distributed Lag (ARDL) approach. African Development Revierw, 29(2), 272-292.

Mishra, A., Mishra, V., \& Smyth, R. (2014). The random-walk hypothesis on the Indian stock market. Discussion Paper No. 07/14 Department of Economics, Monash University.

Narayan, P. K., \& Liu, R. (2015). A unit root model for trending time-series energy variables. Energy Economics, 50, 391402.Available at: https://doi.org/10.1016/j.eneco.2014.11.021.

Narayan, P. K., Narayan, S., \& Westerlund, J. (2015). Do order imbalances predict Chinese stock returns? New evidence from intraday data. Pacific-Basin Finance Journal, 34, 136-151.Available at: https://doi.org/10.1016/j.pacfin.2015.07.003.

Narayan, P. K., \& Popp, S. (2010). A new unit root test with two structural breaks in level and slope at unknown time. Journal of Applied Statistics, 37(9), 1425-1438.Available at: https://doi.org/10.1080/02664760903039883.

Narayan, P. K., \& Popp, S. (2013). Size and power properties of structural break unit root tests. Applied Economics, 45(6), 72 1-728.

Narayan, P. K., Lui, R., \& Westerlund, J. (2016). A GARCH model for testing efficiency. Journal of International Financial Markets, Institutions \& Money, 41, 121 - 138.Available at: https://doi.org/10.1016/j.intfin.2015.12.008.

Nwosa, P. I., \& Oseni, I. O. (2011). Efficient market hypothesis and Nigerian stock market. Research Journal of Finance and Accounting, 2(12), 38-46.

Nwosu, E. O., Orji, A., \& Anagwu, O. (2013). African emerging equity markets re-examined: Testing the weak form efficiency theory. African Development Review, 25(4), 485 - 498.Available at: http://doi:10.1111/1467-8262.12044.

Obrimah, O. A., Alabi, J., \& Ugo-Harry, B. (2015). How relevant is the capital asset pricing model (CAMP) for test of market efficiency on the Nigerian stock exchange? African Development Reviere, 27(3), 262-273.

Olowe, R. A. (1999). Weak form efficiency of the Nigerian stock market: Further evidence. African Development Review, 11(1), 5468.

Oludoyi, S. B. (1997). Capital market efficiency and the effects of earnings announcements on share prices in Nigeria. Unpublished Ph.D Thesis, University of Ibadan, Nigeria.

Omole, D. O. (1997). Efficient market hypothesis and the Nigerian capital market under financial liberalization: An empirical analysis. Unpublished Ph.D Thesis, University of Ibadan, Nigeria.

Otchere, I., \& Abukari, K. (2019). Institutions \& money are super stock exchange mergers motivated by efficiency or market power gains? Journal of International Financial Markets, Institutions \& Money, 101164.Available at: https://doi.org/10.1016/j.intfin.2019.101164.

Phan, D. H. B., Sharma, S. S., \& Narayan, P. K. (2015a). Oil price and stock returns of consumers and producers of crude oil. Journal of International Financial Markets, Institutions and Money, 34, 245-262.Available at: https://doi.org/10.1016/j.intfin.2014.11.010.

Phan, D. H. B., Sharma, S. S., \& Narayan, P. K. (2015b). Stock return forecasting: some new evidence. International Review of Financial Analysis, 40, 38-51.Available at: https://doi.org/10.1016/j.irfa.2015.05.002.

PWC. (2015). 2015 African capital markets watch. Retrieved from www.pwc.co.za/capitalmarketswatch.htmc

Rejichi, I. Z., \& Aloui, C. (2012). Hurst exponent behavior and assessment of the MENA stock markets efficiency. Research in International Business and Finance, 26(3), 353-370.

Salisu, A. A., \& Gupta, R. (2020). Oil shocks and stock market volatility of the BRICS: A GARCH. Global Finance Journal, 100546.Available at: https://doi.org/10.1016/j.gfj.2020.100546.

Salisu, A. A., Vo, X. V., \& Lawal, A. (2020). Hedging oil price risk with gold during COVID-19 pandemic. Resources Policy, 101897.Available at: https://dx.doi.org/10.1016\%2Fj.resourpol.2020.101897. 
Stoian, A., \& Iorgulescu, F. (2020). Fiscal policy and stock market ef fi ciency: An ARDL bounds testing approach. Economic Modelling, 90, 406-416.Available at: https://doi.org/10.1016/j.econmod.2019.12.023.

Stypka, O., \& Wagner, M. (2019). The Phillips unit root tests for polynomials of integrated processes. Economics Letters, 176, 109-113.Available at: https://doi.org/10.1016/j.econlet.2018.12.033.

Vo, X. V., \& Truong, Q. B. (2017). Does momentum work? Evidence from Vietnam stock market. Journal of Behavioral and Experimental Finance.Available at: https://doi.org/10.1016/j.jbef.2017.12.002.

Westerlund, J., Narayan, P. K., \& Zheng, X. (2015). Testing for stock return predictability in a large Chinese panel. Emerging Markets Review, 24, 81-100.Available at: https://doi.org/10.1016/j.ememar.2015.05.004.

Yang, Y., \& Zhao, Z. (2020). Quantile nonlinear unit root test with covariates and an application to the PPP hypothesis. Economic Modelling.

Yaya, O. S., Furuoka, F., Ling, K., Ikechukwu, R., \& Ezeoke, C. M. (2020). Investigating Asian regional income convergence using fourier unit root test with break. International Economics, 161, 120-129.Available at: https://doi.org/10.1016/j.inteco.2019.11.008.

Yilanci, V., \& Korkut, U. (2020). Convergence of per capita ecological footprint among the ASEAN-5 countries: Evidence from a non-linear panel unit root test. Ecological Indicators, 113, 106178.Available at: https://doi.org/10.1016/j.ecolind.2020.106178.

Views and opinions expressed in this article are the views and opinions of the author(s), Asian Economic and Financial Review shall not be responsible or answerable for any loss, damage or liability etc. caused in relation to/arising out of the use of the content. 